\title{
KARAKTERISASI PENGARUH KECEPATAN LAS PADA PENGELASAN MIG AA5083H116 DENGAN ELEKTRODA ER5356
}

\author{
Mudjijana, Moch. Noer Ilman dan Priyo Tri Iswanto \\ Departemen Teknik Mesin dan Industri, Fakultas Teknik \\ Universitas Gadjah Mada \\ e-mail: mudjijana@ugm.ac.id
}

\begin{abstract}
Indonesia is a maritime country where 2/3 of its territory is ocean. Therefore, many ships are needed for transportation from one island to the nother within NKRI region. The AA5083H116 materials are widely used in maritime transportation vehicle due to its low density and high weldability. The research propose is to characterize the influence of welding speed of Metal Inert Gas (MIG) of AA5083H116 using ER5356 electrode on the welded joint properties. The AA5083H116 materials of 3 $\mathrm{mm} \times 1200 \mathrm{~mm} \times 2400 \mathrm{~mm}$ dimension were cut into welding specimens of $3 \mathrm{~mm} \times 75 \mathrm{~mm} \times 300 \mathrm{~mm}$ size. Any pair of specimens was welded using electrode of $0.8 \mathrm{~mm}$ diameter. The welding parameters being used are 19 volts of electrical voltage, 120 amperes of electrical current, and 8, 10, $12 \mathrm{~mm} / \mathrm{s}$ of welding speeds. The characterization were carried out on angle distortion that measured using dial indicator on a milling machine table, $X$-ray radiography test, as well as physical and mechanical properties tests i.e. microstructure, Vickers micro hardness, tensile and bending strength. The research results show that the smallest distortion angle was found at welding speed of $12 \mathrm{~mm} / \mathrm{s}$, all of the welding results satisfy the distortion angle of $<5^{\circ}$, and the radiographic results satisfy the DEPNAKER RI regulation standard. The microstructure exhibits $\mathrm{Al}_{2} \mathrm{Mg}_{3}$ precipitation, Vickers hardness distributions, while the highest tensile and bending strength were obtained at welding speed of $10 \mathrm{~mm} / \mathrm{s}$.
\end{abstract}

Key words: MIG welding, AA5083H116, X-ray radiography, distortion, physical and mechanical properties

\section{PENDAHULUAN}

Metal Inert Gas (MIG) banyak digunakan untuk pengelasan pelat-pelat tipis pada paduan logam non fero dan baja tahan karat. Paduan logam aluminium AA5083H116 banyak digunakan di industri transportasi darat (gerbong kereta api), laut (kapal) dan udara (pesawat).

Paduan aluminium 5083 merupakan paduan logam ringan karena mempunyai berat jenis 2,7 kurang dari 4,5 [1]. Paduan ini mempunyai kandungan Mg 4,5 wt\% dan pada kondisi perlakuan pelarutan lewat jenuh (supersaturated) mempunyai kekuatan luluh $145 \mathrm{MPa}$. Sifat-sifat mekanik paduan aluminium 5083 H111 mempunyai kekuatan tarik (UTS): 307 MPa, kekuatan luluh (YS): $158 \mathrm{MPa}$, regangan $\left(\varepsilon_{\mathrm{f}}\right): 20 \%$ dan kekerasan Vickers $\mathrm{Hv}_{0,2}: 80 \mathrm{~kg} / \mathrm{mm}^{2}$ [2]. Paduan aluminium AA5083H116, kepanjangan dari AA adalah aluminium alloy, 5083 adalah paduan aluminium seri 5 dengan unsur paduan utama Mg, 0 batas ketidakmurnian nol, 83 menunjukkan kemurnian aluminium. $\mathrm{H}$ artinya cold worked (strain hardening), angka 1 pertama menunjukkan cold work only, angka 1 kedua menunjukkan partial solution plus natural ageing, 6 menunjukkan 3/4 keras [3].

Gambar 1 mengilustrasikan rangkaian dari peralatan MIG. Catu daya las berupa arus searah (DC) dengan karakteristik voltase konstan. Peralatan kontrol khusus tidak diperlukan karena mesin lasnya dapat mengatur sendiri busur (self regulating). Gagang las terhubung ke terminal keluaran yang positif melalui mesin pengumpan kawat (wire feeder). Kawat elektroda diumpan dengan kecepatan konstan oleh pengumpan kawat, dan berjalan melalui rangkaian linier kabel las menuju ujung gagang las. Arus las dipasok ke kawat elektroda melalui ujung kontak dalam gagang las. Akibatnya, busur listrik akan terbentuk di antara ujung elektroda dan benda kerja [4,5]. Gambar 2 menunjukkan pengaruh arus dan kecepatan las terhadap bentuk kampuh lasan. Cacat las akibat penetrasi yang tidak sempurna (lack of penetration) terjadi pada daerah $\mathrm{A}$, dimana arus las sangat rendah dan kecepatan las tinggi. Masukan panas yang terjadi tidak cukup untuk mengisi celah las menyebabkan penetrasi tidak sempurna. Cacat las akibat lelehan logam menembus akar las (melt through) terjadi pada daerah B, dimana arus yang diberikan cukup besar serta kecepatan las yang 
rendah. Masukan panas yang berlebihan menyebabkan sambungan yang mencair dan selanjutnya menembus akar lasan. Cacat parit di kaki las (undercut) terjadi pada daerah C, dimana pemberian arus serta kecepatan yang sangat tinggi. Gaya penetrasi dari busur listrik terlalu kuat sehingga mengikis sisi sambungan [4].

(a)

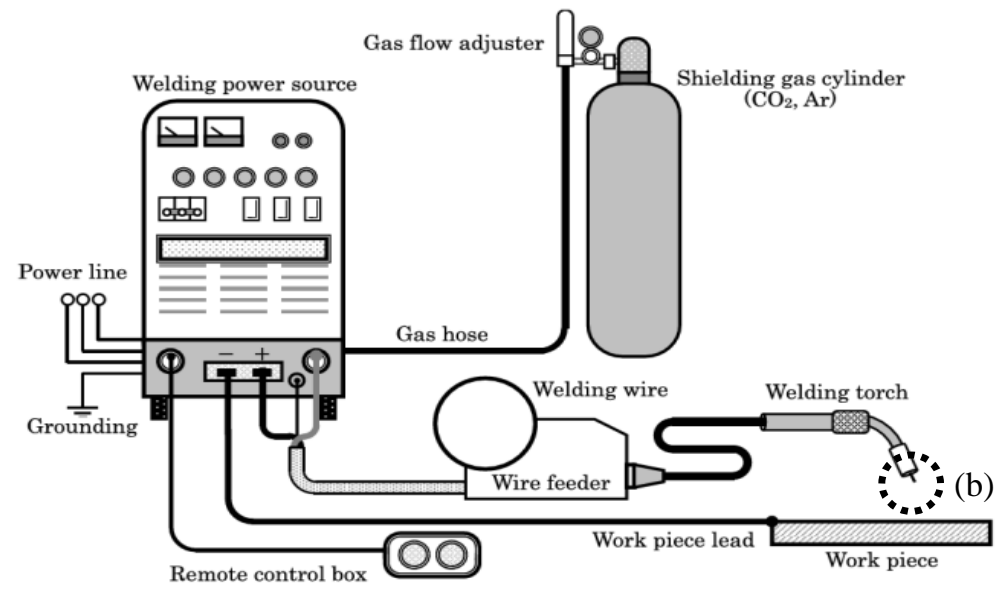

(a)

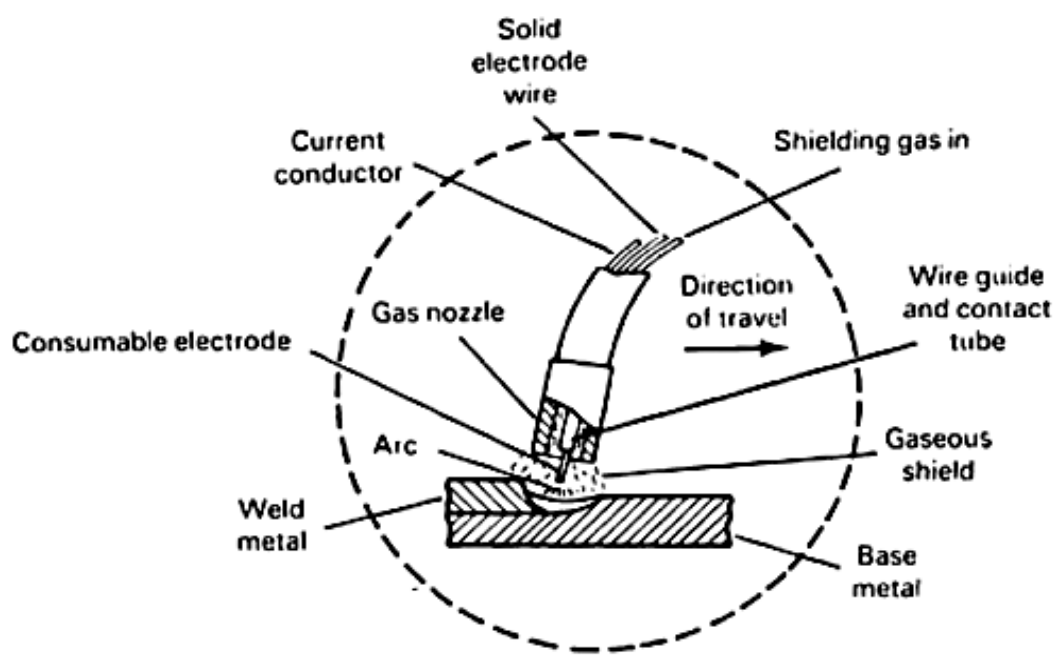

(b)

Gambar 1. (a) Rangkaian peralatan las MIG dengan pelindung gas [4] dan (b) detail torch [5]

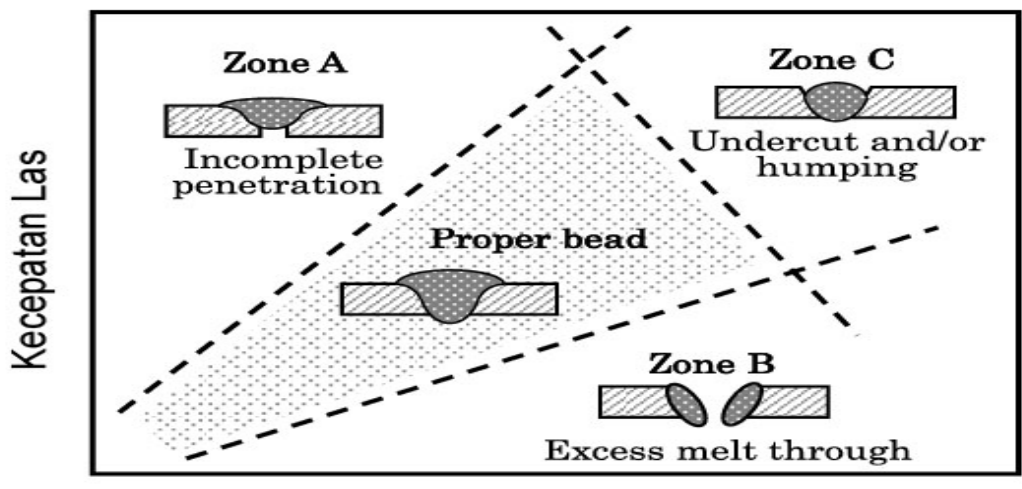

Arus Las (Amper)

Gambar 2. Pengaruh kondisi arus las vs kecepatan las terhadap bentuk kampuh las [4]. 
Distorsi terjadi saat fabrikasi struktur disebabkan oleh perubahan ukuran dasar yang terjadi selama pengelasan: (1) penyusutan melintang terjadi tegak lurus garis las (Gambar 3A), (2) penyusutan memanjang terjadi sejajar garis las (Gambar 3B), (3) perubahan sudut terjadi rotasi di sekitar garis las (Gambar 3C) [6], dan buckling (Gambar 3D) [7].

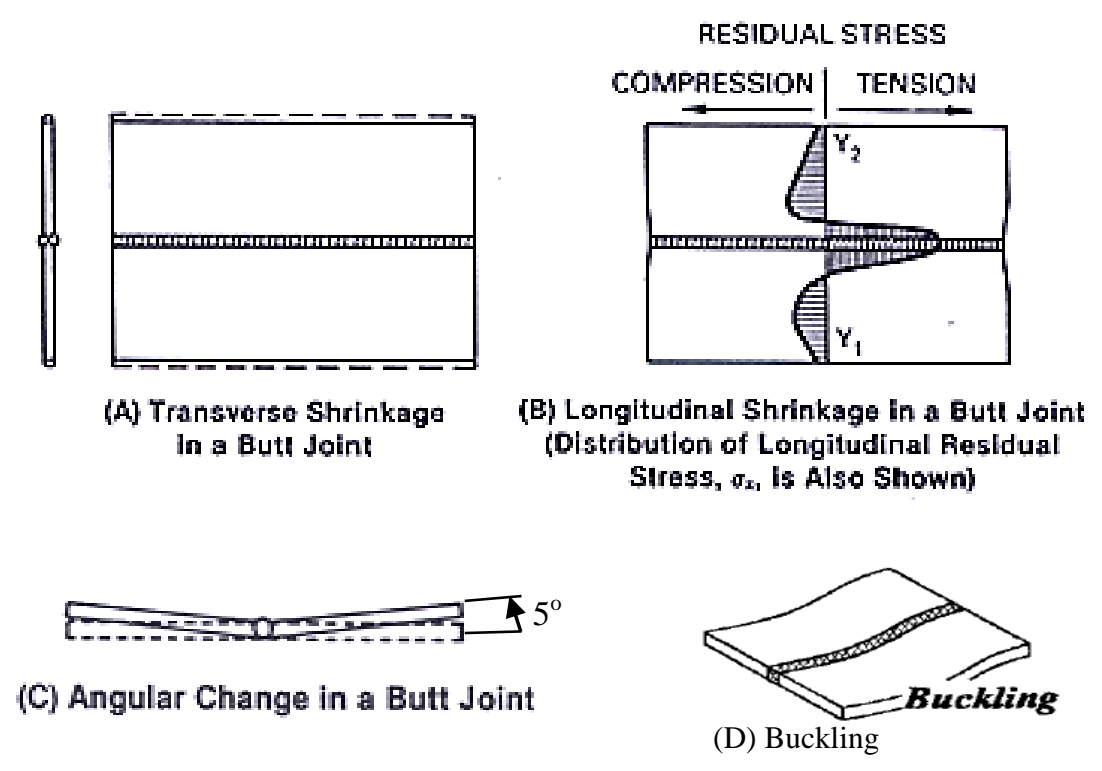

Gambar 3. Jenis-jenis distorsi utama pada pengelasan [6,7].

Deng dan Murakawa [8] melakukan penelitian prediksi distorsi lasan dan tegangan sisa pada butt-welded joint sebuah pelat tipis. Penelitiannya menggunakan 2 pelat baja tipis berukuran 100 $\mathrm{mm}$ x $100 \mathrm{~mm}$ x $1 \mathrm{~mm}$. Pengelasan menggunakan MIG dengan pelindung 80\% $\mathrm{Ar}+20 \% \mathrm{CO}_{2}$ dan kawat las YGW16. Kondisi pengelasan: arus 65A, tegangan 17V, kecepatan pengelasan 780 $\mathrm{mm} / \mathrm{min}$, kecepatan aliran gas pelindung 15 liter/min, tip-to-work distance $25 \mathrm{~mm}$, diameter kawat $0,9 \mathrm{~mm}$, sudut gerakan $45^{\circ}$. Sesudah pengelasan dilakukan pengukuran distorsi dengan cara sederhana yaitu menggunakan vernier caliper untuk 3 sambungan hasilnya 2,20 mm, 1,90 mm dan 2,10 mm. Rata-rata untuk 3 sambungan las adalah 2,067 mm, ini berarti nilai rata-rata distorsi terhadap garis lasan 1,03 mm. James, et al [9] membuat profil tegangan sisa single-line untuk aluminium tebal $8 \mathrm{~mm}$ 5083-H321 yang disambung dengan las MIG. Data diperoleh dengan synchroton diffraction strain scanning. Variasi plate-to-plate tegangan sisa lasan arah memanjang dan melintang sekitar $40 \mathrm{MPa}$. Pengujian struktur mikro lebih efektif pada paduan Al-Mg, menggunakan larutan etsa baru yaitu ammonium persulfate dilarutkan dalam air. Fase $\beta\left(\mathrm{Al}_{3} \mathrm{Mg}_{2}\right)$ dapat diperlihatkan jelas pada paduan biner Al-Mg dan paduan aluminium 5083 komersial. Fase $\beta$ berukuran nanometer tampak jelas diamati menggunakan scanning electron microscope (SEM). Visualisasi fase $\beta$ tampak tambah jelas pada penyelidikan korosi antar butir untuk paduan aluminium seri $5 \mathrm{xxx}[10]$.

Permasalahan pada pengelasan paduan aluminium adalah sulit dihindari terjadinya distorsi pada pengelasan pelat tipis sehingga diperlukan persiapan dan kecermatan dalam melakukan pengelasan. Hal ini disebabkan paduan aluminium mempunyai koefisien muai $\approx 24 \times 10^{-6}\left({ }^{\circ} \mathrm{C}\right)^{-1}$ lebih besar dari paduan logam fero $\approx 12 \times 10^{-6}\left({ }^{\circ} \mathrm{C}\right)^{-1}[12]$

Penelitian ini hanya dilakukan pada pelat AA5083H116 dengan tebal $3 \mathrm{~mm}$ dengan spesimen berukuran panjang $300 \mathrm{~mm}$ dan lebar 75 mm, menggunakan elektroda ER5356 dengan ф0,8 $\mathrm{mm}$, arus $120 \mathrm{~A}$, tegangan $19 \mathrm{~V}$, aliran gas argon 17 liter/menit.

Tujuan penelitian ini adalah mengkarakterisasi pengaruh kecepatan las pada pengelasan MIG (Metal Inert Gas) AA5083 H116 dengan elektroda ER5356 yang akan mendukung proses produksi canoe atau kapal untuk pengembangan maritime di NKRI. 


\section{METODE PENELITIAN}

Bahan penelitian menggunakan pelat AA5083H116 berukuran $3 \mathrm{~mm}$ x $300 \mathrm{~mm}$ x $75 \mathrm{~mm}$ dan elektroda ER5356 berdiameter $0,8 \mathrm{~mm}$, dimana arah pengelasan melintang terhadap arah pengerolan. Pengelasan menggunakan mesin las Tenjima MIG 200S dan gas argon sebagai pelindungnya. Pengelasan dilakukan semiotomatis dengan sudut pengelasan $45^{\circ}$ dan jarak busur las dengan spesimen $2 \mathrm{~mm}$, menggunakan arus $120 \mathrm{~A}$, tegangan $19 \mathrm{~V}$, laju aliran gas argon 17 liter/menit, kecepatan las 8, 10, $12 \mathrm{~mm} / \mathrm{s}$. Dua spesimen di tack weld dan diklem di enam titik ditunjukkan pada Gambar 4. Hasil lasan diuji radiografi $X$-ray menggunakan alat LORAD LPX-200 ada di STTN BATAN Babarsari, Yogyakarta, mempunyai energi potensial sampai dengan 200KV dan arus tabung hingga 10mA. Distorsi hasil sambungan las MIG AA5083H116 dengan elektroda ER5356 diukur menggunakan dial indikator yang dijepit magnetic base stand dengan ketelitian 0,01 mm sepanjang arah garis las sumbu $\mathrm{x}$, arah tegak lurus garis las $\mathrm{y}$, arah tegak lurus bidang las $\mathrm{z}$, dan dilakukan diatas meja mesin Frais. Selanjutnya, hasil lasan diamati struktur mikro menggunakan mikroskop optik pada penampang lintang lasan dengan etsa $1 \mathrm{ml} \mathrm{HF}, 1,5 \mathrm{ml} \mathrm{HCl}, 2,5 \mathrm{ml} \mathrm{HNO}$, 9,5ml aquades; hasil uji kekerasan (ASTM E92) mikroVickers 3 titik di rata-rata menggunakan beban 100 gram di daerah BM (Base Metal), HAZ (Heat Affected Zone), dan WM (Weld Metal); uji tarik (ASTM E8) dan bending (ASTM D 790) menggunakan 2 spesimen dengan hasil pengujian di rata-rata, seperti ditunjukkan pada Gambar 4.

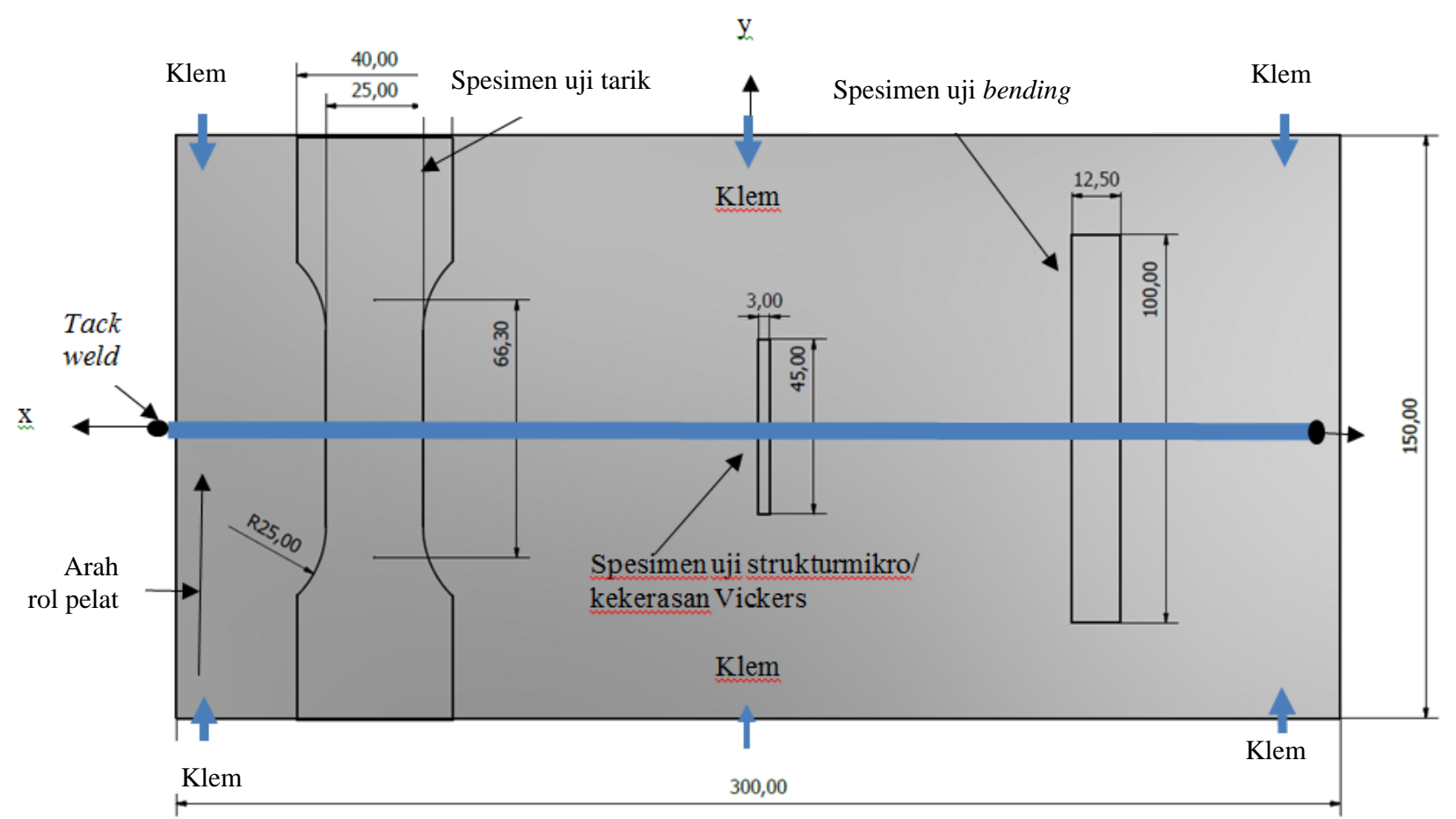

Gambar 4. Spesimen uji struktur mikro, kekerasan Vickers, tarik, dan bending.

\section{HASIL DAN PEMBAHASAN \\ Hasil Pengujian Radiografi}

Hasil radiografi pengelasan MIG bahan AA5083H116 dengan elektroda ER5356 ditunjukkan pada Gambar 5, menunjukkan adanya porositas pada semua plat pada kecepatan las 8, 10 dan $12 \mathrm{~mm} / \mathrm{s}$. Garis halus cukup panjang yang terjadi pada plat hasil lasan merupakan line porosity. Hal ini mungkin disebabkan laju filler atau gas argon yang kurang cepat sehingga gas oksigen masuk kedalam bagian lasan. Ukuran porositas yang muncul di radiografi memiliki batas maksimal yang diperbolehkan seperti disajikan pada Tabel 1, menyajikan standarisasi yang diperbolehkan menurut Menteri Tenaga Kerja RI [10]. Pada penelitian ini jumlah porositas yang terjadi termasuk katagori halus disajikan pada Tabel 2. Hasil las MIG terbaik berdasarkan hasil 
radiografi adalah pada kecepatan las $8 \mathrm{~mm} / \mathrm{s}$ karena memiliki jumlah porositas terendah dibandingkan las 12 dan $10 \mathrm{~mm} / \mathrm{s}$. Namun perlu dikonfirmasi terlebih dahulu dengan hasil pengujian kekerasan Vickers, tarik, dan bending.

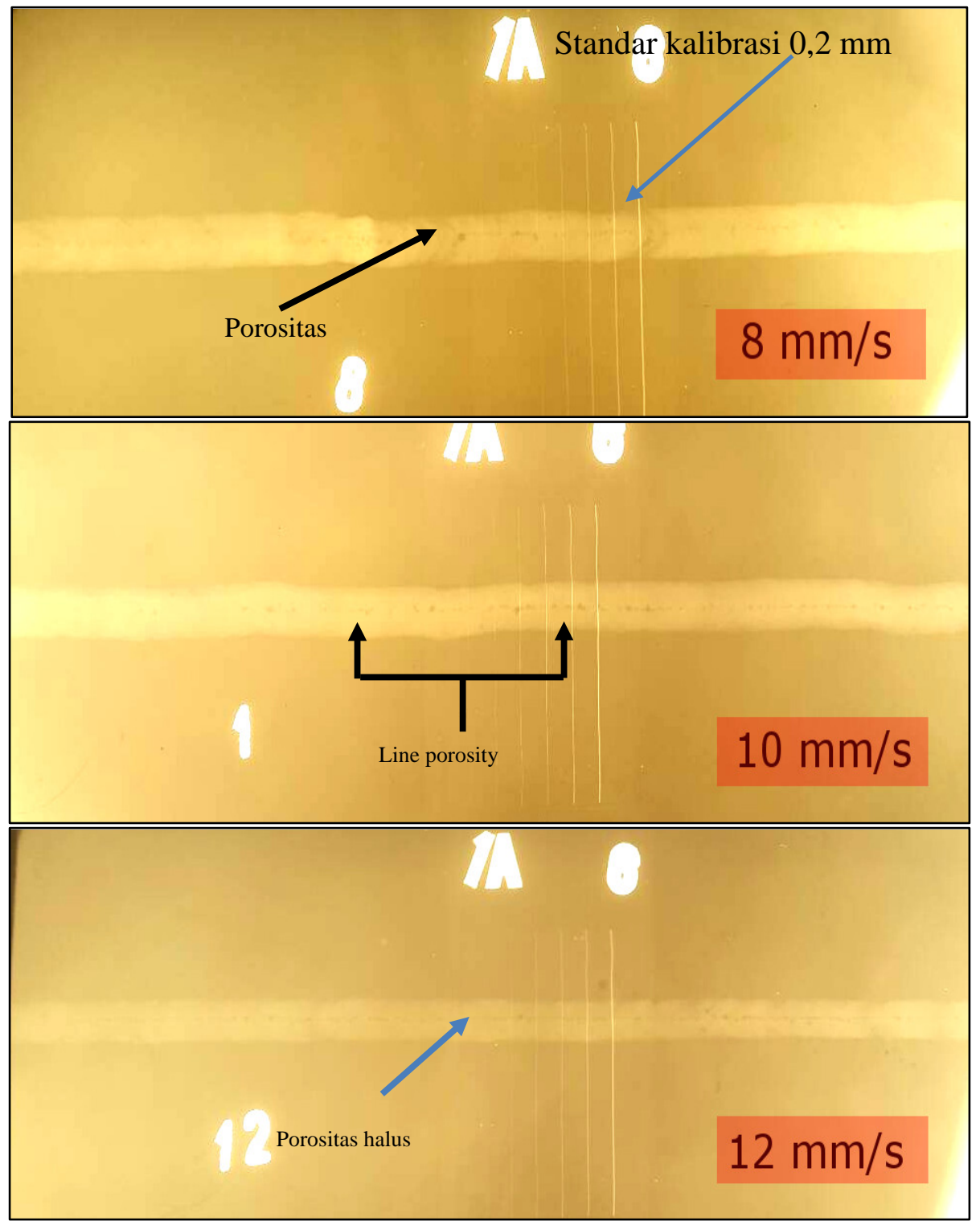

Gambar 5. Hasil radiografi las MIG pada kecepatan las 8, 10 dan 12 mm/s.

Tabel 1. Ukuran porositas yang diperbolehkan [11]

\begin{tabular}{|c|c|c|c|c|c|c|c|}
\hline \multirow[b]{2}{*}{$\begin{array}{l}\text { Tebal } \\
\text { Pelat }\end{array}$} & \multicolumn{6}{|c|}{ Ukuran liang-liang renik (gelembung gas) mm } & \multirow{2}{*}{$\begin{array}{c}\text { Jumlah } \\
\text { liang } \\
\text { renik }\end{array}$} \\
\hline & $\begin{array}{c}\text { Ukuran } \\
\text { Besar }\end{array}$ & Jumlah & $\begin{array}{l}\text { Ukuran } \\
\text { sedang }\end{array}$ & Jumlah & $\begin{array}{c}\text { Ukuran } \\
\text { Halus }\end{array}$ & Jumlah & \\
\hline 3 & - & - & - & - & 0,4 & 49 & 4 , \\
\hline 6 & - & - & 0,6 & 31 & 0,4 & 100 & 10 \\
\hline 12 & 2,5 & 4 & 0,8 & 40 & 0,5 & 101 & 19 \\
\hline 19 & 3 & 4 & 0,9 & 50 & 0,6 & 99 & 29 \\
\hline
\end{tabular}

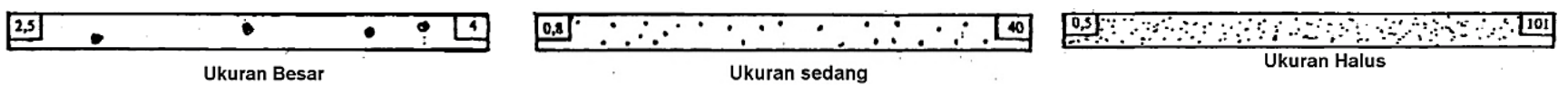


Tabel 2. Ukuran porositas pada kecepatan las 8, 10, $12 \mathrm{~mm} / \mathrm{s}$,

\begin{tabular}{ccc} 
Kecepatan las (mm/s) & Jumlah ukuran halus & $\begin{array}{c}\text { Lulus uji (porositas ukuran } \\
\text { halus }<49)\end{array}$ \\
$\mathbf{8}$ & 15 & Ya \\
$\mathbf{1 0}$ & 31 & Ya \\
$\mathbf{1 2}$ & 21 & Ya \\
\hline
\end{tabular}

\section{Hasil Pengukuran Distorsi}

Pengukuran distorsi dilakukan pada arah x, y dan z sebanyak 155 titik. Pada tulisan ini hanya ditunjukkan rata-rata puncak distorsi seperti disajikan pada Tabel 3 pada jarak 62,5 mm dari garis las. Rata-rata puncak distorsi yang paling kecil terjadi pada kecepatan las $12 \mathrm{~mm} / \mathrm{s}$ disebabkan masukan panas (Q) yang terjadi lebih kecil dari pada kecepatan las 8 dan $10 \mathrm{~mm} / \mathrm{s}$. Puncak distorsi yang terjadi pada hasil lasan AA5083H116 dengan elektroda ER5356 lebih tinggi daripada hasil lasan pelat baja tipis [8], hal ini disebabkan koefisien muai paduan aluminium lebih besar dari pelat baja [12].

Tabel 3. Rata-rata puncak distorsi arah sumbu y-y pada pengelasan MIG

\begin{tabular}{ccc}
\hline \multirow{2}{*}{ Laju pengelasan } & \multicolumn{2}{c}{ Rata-rata puncak distorsi } \\
\cline { 2 - 3 } & $-\mathrm{y}=62,5 \mathrm{~mm}$ & $+\mathrm{y}=62,5 \mathrm{~mm}$ \\
\hline $12 \mathrm{~mm} / \mathrm{s}$ & 1,065 & 1,53 \\
$10 \mathrm{~mm} / \mathrm{s}$ & 2,5 & 2,14 \\
$8 \mathrm{~mm} / \mathrm{s}$ & 5,12 & 3,5 \\
\hline
\end{tabular}

\section{Hasil Pemeriksaan Struktur Mikro}

Struktur mikro bahan AA5083H116 as received ditunjukkan pada Gambar 5(a), sedangkan struktur mikro hasil lasan MIG pada kecepatan las $10 \mathrm{~mm} / \mathrm{s}$ menggunakan elektroda ER5356 ditunjukkan pada Gambar 5 (b), (c) dan (d). Struktur mikro terdiri dari fase $\alpha$ (Al) dan fase $\beta$ $\left(\mathrm{Al}_{2} \mathrm{Mg}_{3}\right)$. Hasil struktur mikro pada kecepatan las 8 dan $12 \mathrm{~mm} / \mathrm{s}$ (tidak ditampilkan) distribusi ukuran butir kurang seragam dibanding dengan pada kecepatan las $10 \mathrm{~mm} / \mathrm{s}$. Hal ini dibuktikan dengan hasil uji kekerasan Vickers mempunyai fluktuasi nilai daerah BM, HAZ dan WM lebih besar. Presipitasi $\mathrm{Al}_{2} \mathrm{Mg}_{3}$ kurang begitu jelas, sehingga pada penelitian selanjutnya perlu menggunakan etsa ammonium persulfate [10].

\section{Hasil Pengujian Kekerasan, Tarik dan Bending.}

Hasil pengujian kekerasan, tarik, bending bahan AA5083H116 as received dan hasil pengelasan MIG menggunakan elektroda ER5356 pada welding speed 8, 10 dan $12 \mathrm{~mm} / \mathrm{s}$ disajikan pada Tabel 4. Efisiensi las dapat dihitung dengan $\eta=\frac{\text { kekuatan tarik lasan }}{\text { kekuatan tarik as received }}$, sedangkan masukan panas dapat dihitung dengan $\mathrm{Q}=\frac{\eta V I}{v}, \mathrm{~V}=$ tegangan las, (volts), $\mathrm{I}=$ arus las (ampere), $\mathrm{v}=$ kecepatan las $(\mathrm{mm} / \mathrm{s})$. 

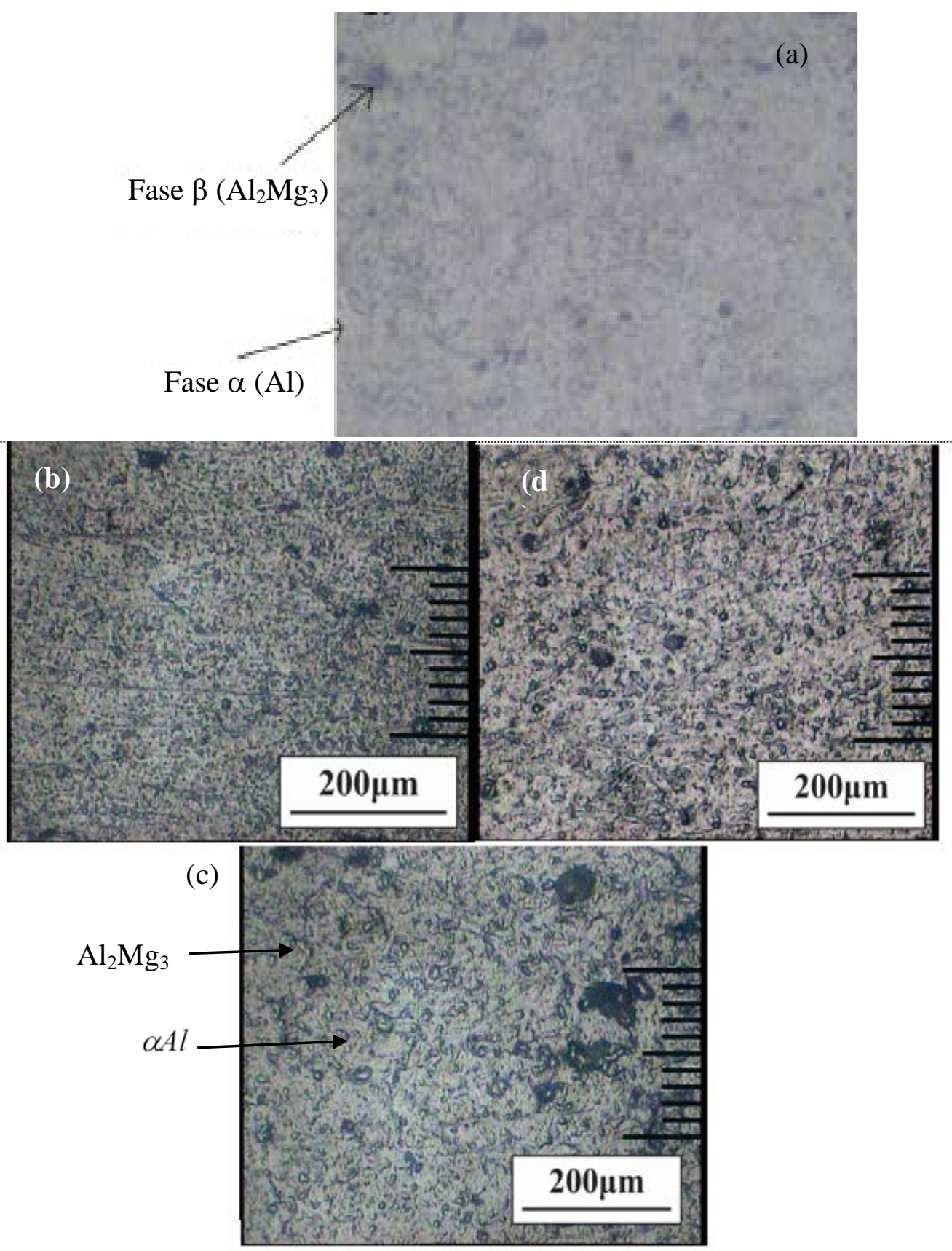

Gambar 6. (a) Struktur mikro AA5083H116 as received; (b) struktur mikro BM, (c) HAZ dan (d) WM pada welding speed $10 \mathrm{~mm} / \mathrm{s}$

Hasil patahan makro pada pengujian tarik ditunjukkan pada Gambar 6 (a), (b) dan (c), tampak pada laju pengelasan $10 \mathrm{~mm} / \mathrm{s}$ mempunyai permukaan kurang rata dibandingkan dengan dengan laju pengelasan 8 dan $12 \mathrm{~mm} / \mathrm{s}$. Hal ini sesuai, bila dikorelasikan antara hasil uji kekerasan Vickers, uji tarik, uji bending, dan hasil foto makro maka pada laju las $10 \mathrm{~mm} / \mathrm{s}$ mempunyai sifat tarik kekuatan luluh, tarik, regangan, dan efisiensi las paling besar dibanding laju pengelasan 8 dan $12 \mathrm{~mm} / \mathrm{s}$. Disamping itu, nilai kekerasan Vickers rata-rata di BM, HAZ dan WM paling rendah dibanding laju pengelasan 8 dan $12 \mathrm{~mm} / \mathrm{s}$. Hal ini menunjukkan juga hasil proporsional dengan nilai regangan paling tinggi dibanding lainnya. Jadi, bila nilai kekerasannya kecil mempunyai nilai keuletan atau regangan besar. Selain itu, didukung pula dengan hasil pengujian bending pada laju pengelasan $10 \mathrm{~mm} / \mathrm{s}$ yang mempunyai nilai paling besar. 

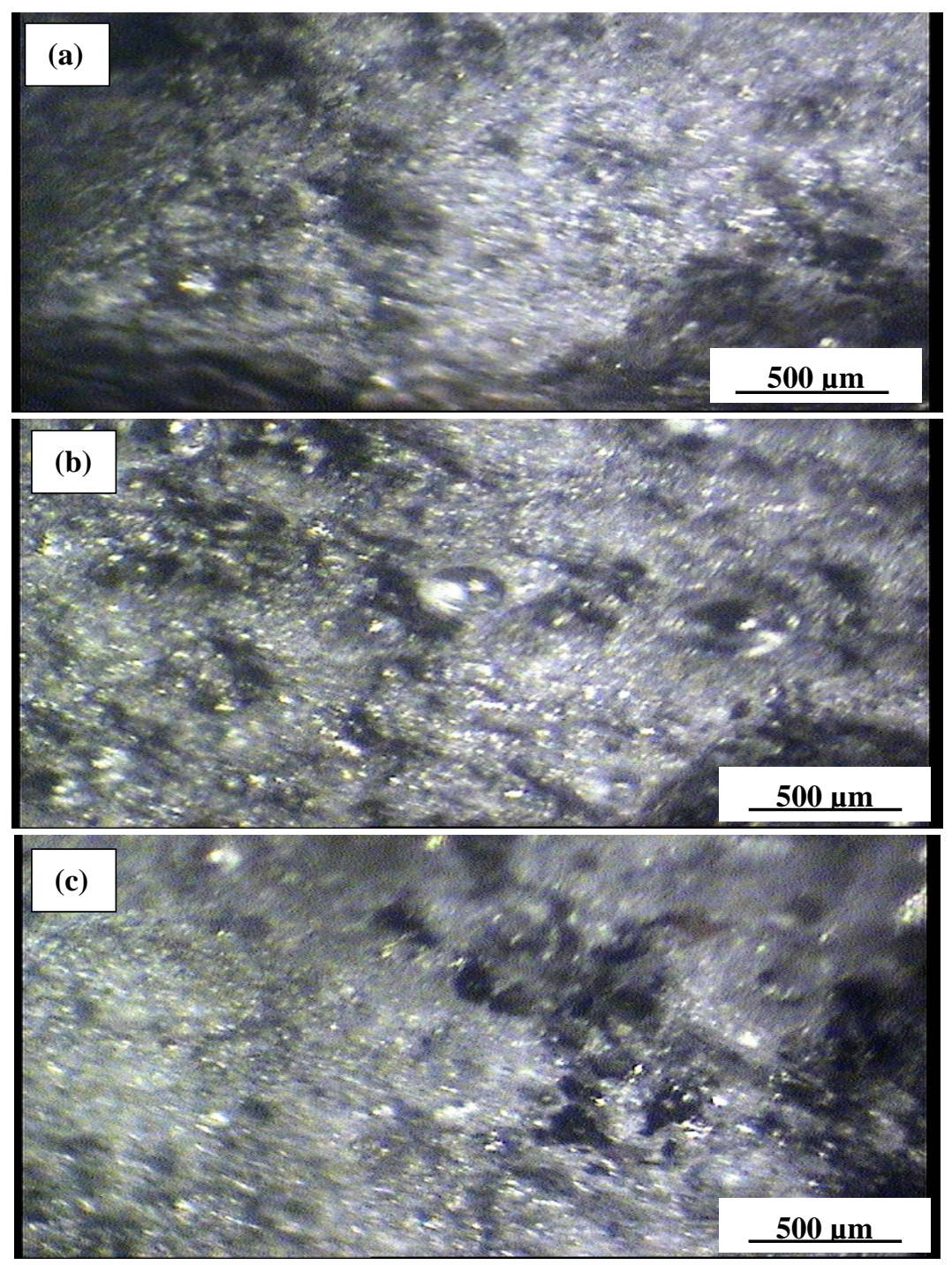

Gambar 7. Patahan makro untuk kecepatan las : (a) 8 mm/s, (b) 10 mm/s dan (c) $12 \mathrm{~mm} / \mathrm{s}$.

Tabel 4. Hasil pengujian kekerasan Vickers, tarik, dan bending bahan AA5083H116 as received dan di las MIG dengan elektroda ER5356 pada welding speed 8, 10 dan 12 mm/s

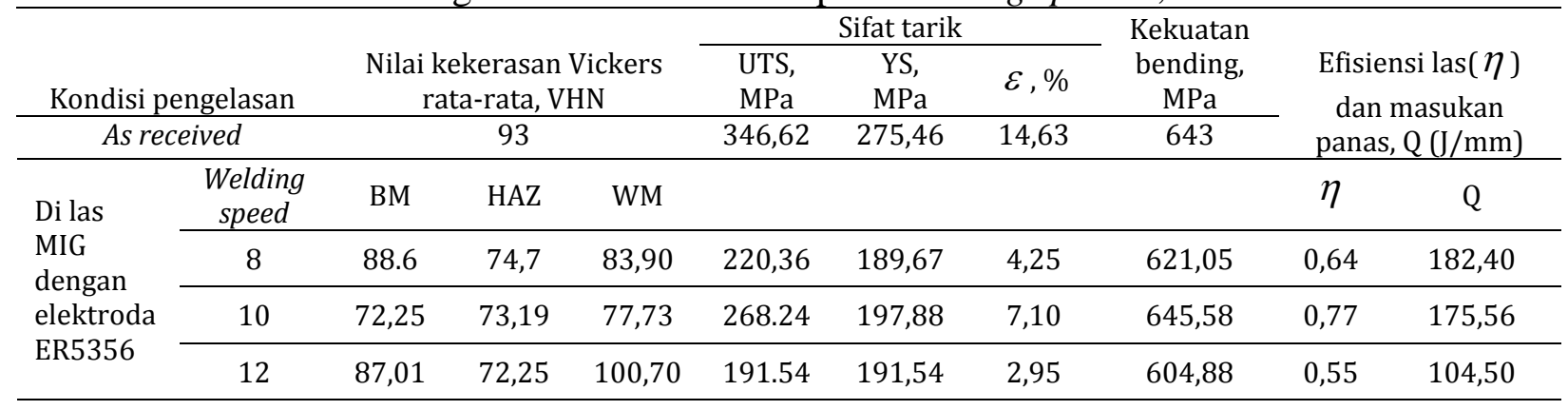

Hasil pengujian tarik AA5083H116 as received nilai kekuatan tarik maksimum (UTS) dan luluh (YS), dan kekerasan (Tabel 4) lebih tinggi dari hasil pengujian tarik 5083H111 [2]. Hal ini disebabkan proses pengerasan yang dilakukan pada 5083H111 hanya $1 / 4$ keras, sedangkan pada AA5083H116 dilakukan 3/4 keras yang menghasilkan ukuran butir lebih kecil. Pengaruh proses pengelasan bahan AA5083H116 terjadi penurunan sifat-sifat fisik dan mekanik logam induk (BM) menurun disebabkan adanya proses perlakuan panas normalizing dan hasil pengelasan ada porositas yang tidak bisa dihindarkan. 
Pada pengujian bending tegangan yang terjadi merupakan kombinasi tegangan tarik dan tegangan tekan. Jadi, pada laju pengelasan $10 \mathrm{~mm} / \mathrm{s}$ pada bahan AA5083H116 dengan elektroda ER5356 adalah kondisi laju pengelasan paling bagus dengan menggunakan arus 120A, tegangan 19V, dan laju aliran gas argon 17 liter/menit. Hal ini didukung pula struktur mikro pada laju pengelasan $10 \mathrm{~mm} / \mathrm{s}$ mempunyai distribusi presipitat $\mathrm{Al}_{2} \mathrm{Mg}_{3}$ yang lebih merata dibanding pada laju pengelasan 8 dan $12 \mathrm{~mm} / \mathrm{s}$ walaupun jumlah rongga halus pada laju pengelasan ini paling banyak, namun dimungkinkan volume total rongga halus pada laju pengelasan $10 \mathrm{~mm} / \mathrm{s}$ paling sedikit.

\section{SIMPULAN}

Hasil pemeriksaan radiografi menunjukkan untuk kecepatan las 8, 10 dan $12 \mathrm{~mm} / \mathrm{s}$ semua memenuhi persyaratan DEPNAKER RI. Semakin tinggi kecepatan las, maka semakin rendah distorsi yang dihasilkan disebabkan masukan panas yang terjadi lebih rendah. Selanjutnya pengelasan bahan AA5083H116 menggunakan elektroda ER5356 pada kecepatan las $10 \mathrm{~mm} / \mathrm{s}$ menghasilkan sifat-sifat fisik dan mekanik paling baik dengan arus $120 \mathrm{~A}$, tegangan $19 \mathrm{~V}$, masukan panas 175,56 J/mm, dan aliran gas argon 17 liter/menit. Perlu dilakukan penelitian lebih lanjut endapan presipitat $\mathrm{Al}_{2} \mathrm{Mg}_{3}$ menggunakan SEM dan EDS menggunakan etsa ammonium persulfate.

\section{UCAPAN TERIMA KASIH}

Ucapan terima kasih disampaikan kepada Departemen Teknik Mesin dan Industri, Fakultas Teknik UGM yang telah memberi dana penelitian dengan No. Kontrak: 1565/H1.17/TMI/LK/2016 dan Menristek dikti melalui Penelitian Unggulan Perguruan Tinggi (PUPT) dengan No. Kontrak: 015/SP2H/LT/DRPM/II/2016, saudara Abdan Faiz Fadhlullah, Teddy Maulana Putra dan M. Dede Azandri yang telah membantu penelitian ini.

\section{DAFTAR PUSTAKA}

[1]. Ashby, M.F., Jones, D. R., 2013, Engineering Material 2 an Introduction to Microstructures and Processing, $4^{\text {th }}$ Edition, 189-192, Elsevier.

[2]. Borrego, L.P, Costa, J.D., Jesus, J.S., Loureiro, A.R., Ferreira, J.M., 2014, Fatigue life Improvement by friction stir processing of 5083 aluminium alloy MIG butt welds, Theoretical and Applied Fracture Mechanics 70 (2014), 68-74, Elsevier.

[3]. Udomphol, T., 2007, Aluminium and its alloys, Suranaree University of Technology.

[4]. Winarto, 2011, Buku Pegangan "Teknologi Pengelasan”, Japan International Cooperation Agency, pp. 16-36.

[5]. ASM Handbook, 1998, Welding, Brazing, and Soldiring, Volume 6, ASM International, p. 2596.

[6]. ------ , 1997, Materials and Welding, Part 2, American Bureau of Shipping, Two World Trade Center $106^{\text {th }}$ Floor, New York, N.Y. 10048, U.S.A.

[7]. Goldak, J.A., and Akhlaghi, M., 2005, Computational Welding Mechanics, Springer Science + Business Media, Inc. Printed in the United States of America.

[8]. Deng, D., Murakawa, H., 2008, Prediction of welding distortion and residual stress in thin plate butt-welded joint, Computational Materials Science 43 (2008) 353-365, Elsevier.

[9]. James, M.N., Hughes, D.J., Hattingh, D,G., Webster, P.J., 2009, Residual stress and strain in MIG butt welds in 5083-H321 aluminium As-welded and fatigue cycled, International Journal of Fatigue 31 (2009), 28-40, Elsevier.

[10]. Yang, Y.K. dan Allen, T., 2013, Direct visualization of $\beta$ phase causing intergranular forms of corrosion in Al-Mg alloys, Materials Characterization 80, 76-85, Elsevier.

[11]. Zain, H., 1982, Peraturan Menteri Tenaga Kerja dan Transmigrasi No: PER.02/MEN/1982, Tentang Kwalifikasi Juru Las di Tempat Kerja, Kementrian Tenaga Kerja dan Trasmigrasi RI.

[12]. Callister, W.D., Rethwisch, D.G., 2012, Fundamentals of Materials Science and Engineering, an Intergrated Approach, $4^{\text {th }}$ Edition, John Wiley \& Sons, Inc. 